\title{
Femur uniapikal deformitelerinin tedavisi
}

\section{Treatment of uniapical deformities of the femur}

\author{
Cengiz Şen ${ }^{1}$, Yavuz Sağlam¹, Melih Civan² \\ 'İstanbul Üniversitesi, İstanbul Tıp Fakültesi, Ortopedi ve Travmatoloji Anabilim Dalı, İstanbul \\ ${ }^{2}$ Gaziosmanpaşa Eğitim ve Araştırma Hastanesi, Ortopedi ve Travmatoloji Kliniği, İstanbul
}

\begin{abstract}
Alt ekstremite uzun kemiklerinin frontal plandaki açısal deformiteleri, vücut ağırlığının yere iletilmesinde bir iz düşüm olan mekanik eksenin yer değiştirmesi ile sonuçlanır. Telafi mekanizması olsun ya da olmasın, deformite femur, tibia ya da her ikisinde de olabilir. Bu deformiteler, uzun kemik diyafizlerinde ya da ekleme yakın bölgelerde (juksta-artiküler) bir oryantasyon kusuru olarak da görülebilir. Hastalar sıklıkla yürüme bozukluklarından ve ağrılardan şikayet etmektedir. Fonksiyonel kısıtlılıklarının yanında, kozmetik ve psikolojik endişeler de zorlayıcı etmenler arasında yer alır. Tedavide ilk basamak, deformitelerin ölçülebilir ve sistematik parametrelerle tanımlanması, hastanın hayatına ve kliniğine etkisinin tespit edilmesidir. Sonuçta bu tanımlamalar ve hesaplamalar tedavi seçiminde kullanılacaktır. Bu makalede femur uniapikal defomitelerinin dünyaca yaygın olarak kabul edilen prensipler doğrultusunda analiz ve tedavi seçenekleri anlatılacaktır.
\end{abstract}

Anahtar sözcükler: deformite; femur; uniapikal
Frontal plane angular deformities of the lower limbs are related with the mechanical axis deviation which represents the trajectory of the body weight. Femur, tibia or both could be affected with or without compensation. The deformities could be positioned at the the diaphyseal area or juxta-articular region as a malorientation of the joint. Patients are mostly suffered with gait abnormalities and pain. Cosmetic and psychologic concerns along with the functional limitations are also challenging. The first step of the treatment is to define the deformity a systematic and quantitative aspect and determine the effects of these measurements to the symptomatology and daily life. At the end, these definitions and calculations will be used in the treatment choice. In this article, analysis and treatment options of the femur uniapical deformities will be discussed by the manner of the commonly accepted worldwide principles.

Key words: deformity; femur; uniapical
F rontal plan deformitelerinin analizi, dizilim ve yönelim olmak üzere iki temel kavram üzerinden yapılır. Anatomik bir dizilimde, femur başının, dizin ve ayak bileğinin orta noktaları, aynı doğru üzerinde bulunmalıdır (Şekil 1-3). Bu doğru, alt ekstremitenin mekanik eksenini oluşturur. Frontal plan deformitelerinde, bu mekanik eksen medial ya da lateral doğrultuda yer değiştirir. Yer değiştirme diyafiz kaynaklı bir deformite sebebi ile olabildiği gibi, proksimal ya da distal eklem bölgesi deformiteleri ya da oryantasyon bozukluklarından da kaynaklanabilir (Şekil 4, 5).

Mekanik eksen sapması "Kötü Dizilim (Malalignment) Testi" ile tespit edilir. Bu testin sonunda hangi kemiğin deformitenin kaynağı olduğu anlaşılır. Daha sonra tibia ve femur ayrı ayrı değerlendirilir. Her kemiğin proksimal ve distal segmentleri arasındaki mekanik eksen açılanmaları tespit edildikten sonra "Kötü Yönelim Testi” yapılarak, eklem maloryantasyonları tespit edilir. ${ }^{[1]}$

\section{ENDIKASYONLAR, HASTA SEÇiMi ve PREOPERATIF HAZIRLIK}

Açısal femur deformitelerinin tedavisinde mekanik eksen sapması ve eklem maloryantasyonu belirleyicidir. Normal anatomiden $15 \mathrm{~mm}$ ve daha fazla mekanik eksen sapması durumunda, proksimal femur için $110^{\circ}$ ile $140^{\circ}$ arası değerler dışındaki boyun şaft açısında, distal femurda $5^{\circ}$ 'den fazla eklem maloryantasyonunda, diyafizer bölgede ise $10^{\circ}$ 'den fazla açısal deformite varlığında cerrahi düzeltme ameliyatları uygulanır.

- İletişim adresi: Prof. Dr. Cengiz Şen, İstanbul Üniversitesi İstanbul Tıp Fakültesi, Ortopedi ve Travmatoloji Anabilim Dalı, Fatih, İstanbul Tel: 0532 - 2456365 e-posta: senc64@gmail.com

- Geliș tarihi: 21 Kasım 2019 Kabul tarihi: 4 Aralık 2019 


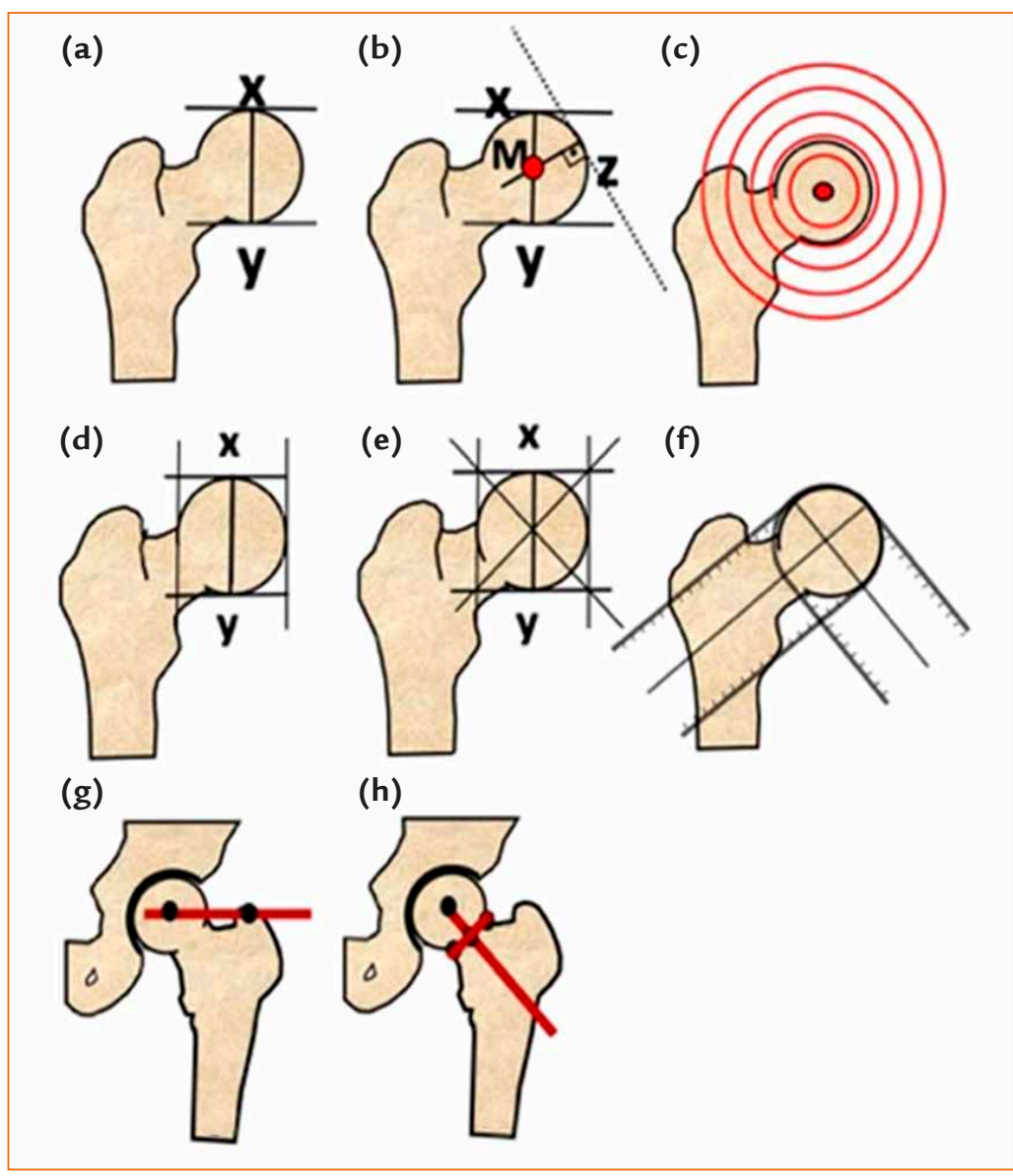

Şekil 1. a-h. Femur başı orta noktasının farklı hesaplanma metotları ve proksimal femur referans noktaları. Daire dik açısı metodu (a, b). Mose halkaları yöntemi (c). Köşegen metodu (d, e). Gonyometre metodu (f). Proksimal femur eklem oryantasyon çizgisinin çizilmesi (g). Femur boynu anatomik ekseninin çizilmesi (h). (Çakmak M, Şen C, editörler. Deformite Cerrahisinde ilizarov Uygulamaları. Istanbul: Nobel Tıp Yayınevi; 2014'ten izinle alıntılanmıştır.)

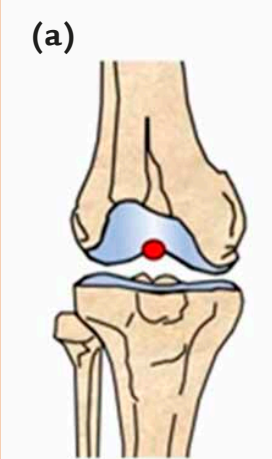

(c)

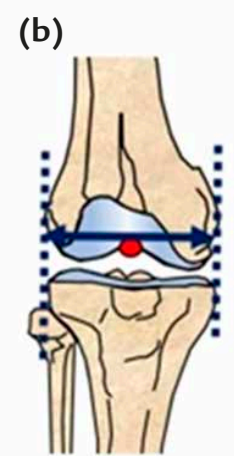

(d)

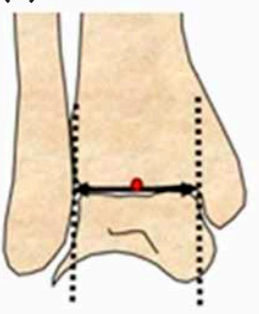

(e)

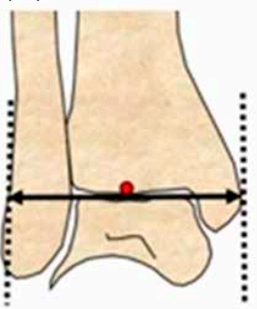

(f)
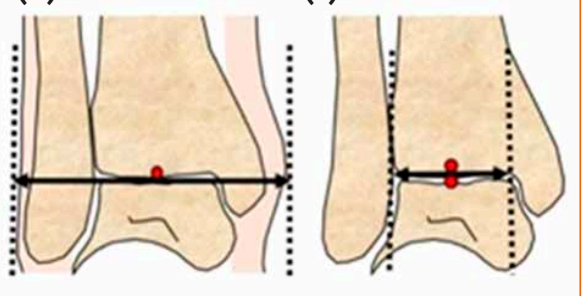

Şekil 2. a-f. Diz (a, b) ve ayak bileği (c-f) eklemi orta noktalarının belirlenmesi. (Çakmak M, Şen C, editörler. Deformite Cerrahisinde ilizarov Uygulamaları. İstanbul: Nobel Tıp Yayınevi; 2014'ten izinle alıntılanmıştır.)
Deformite cerrahisinde endikasyonlar; ölçülebilir değerler üzerinden yapılan deformite analizinin yanında, hastanın klinik, kozmetik, psikolojik durumu ve hatta hasta bakımını sağlayacak aile ve sosyal çevre koşulları ile belirlenir. Bu tip uygulamalarda ameliyat başarısı ne kadar üst düzeyde olursa olsun, ameliyat sonrası bakım, hasta uyumu, ortopedik fizik tedavi ve rehabilitasyon, tedavi başarısının diğer yarısını oluşturur. Kozmetik sebeplerle yapılan düşük dereceli düzeltmeler öncesinde, hastanın psikostabilitesinin belirlenmesi de faydalı olacaktır.

Hastaların radyolojik değerlendirmelerinden önce detaylı anamnez ve fizik muayene yapılması mutlaka gereklidir. Bu muayeneler esnasında hastalar klinik ve fonksiyonel olarak değerlendirilir. Etkilenen ve karşı uzuvdaki tüm büyük eklemlerin hareket açıklıkları ve kontraktürleri kayıt edilmelidir. Kas güçsüzlükleri, nörolojik ve vasküler durum, cilt skarları ve sekelleri ameliyat öncesi kayıt altına alınması gereken diğer parametrelerdir.

Anamnez ve fiziki muayeneden sonra hastalara deformite analizi yapılır. Deformite analizinde ilk olarak malalignment (kötü dizilim) testi yapılır. Malalignment testi sonucunda, mekanik eksen sapmasının (MAD) yalnızca femur kaynaklı olduğu tespit edilir (Şekil 6a). $\mathrm{Bu}$ işlemden sonra tibia normal ise femurun analizine odaklanılır. Kalça, diz ve ayak bileğinin eklem oryantasyon hatları çizilir. Ayak bileği ortasından diz ortasına tibia mekanik ekseni çizilir ve $87^{\circ}$ 'lik açı ile proksimale doğru uzatılır. Böylelikle distal femurun olması gereken mekanik ekseni çizilmiş olur. Eğer tibia ve femurda deformite mevcutsa her iki kemiğin eklem oryantasyon 


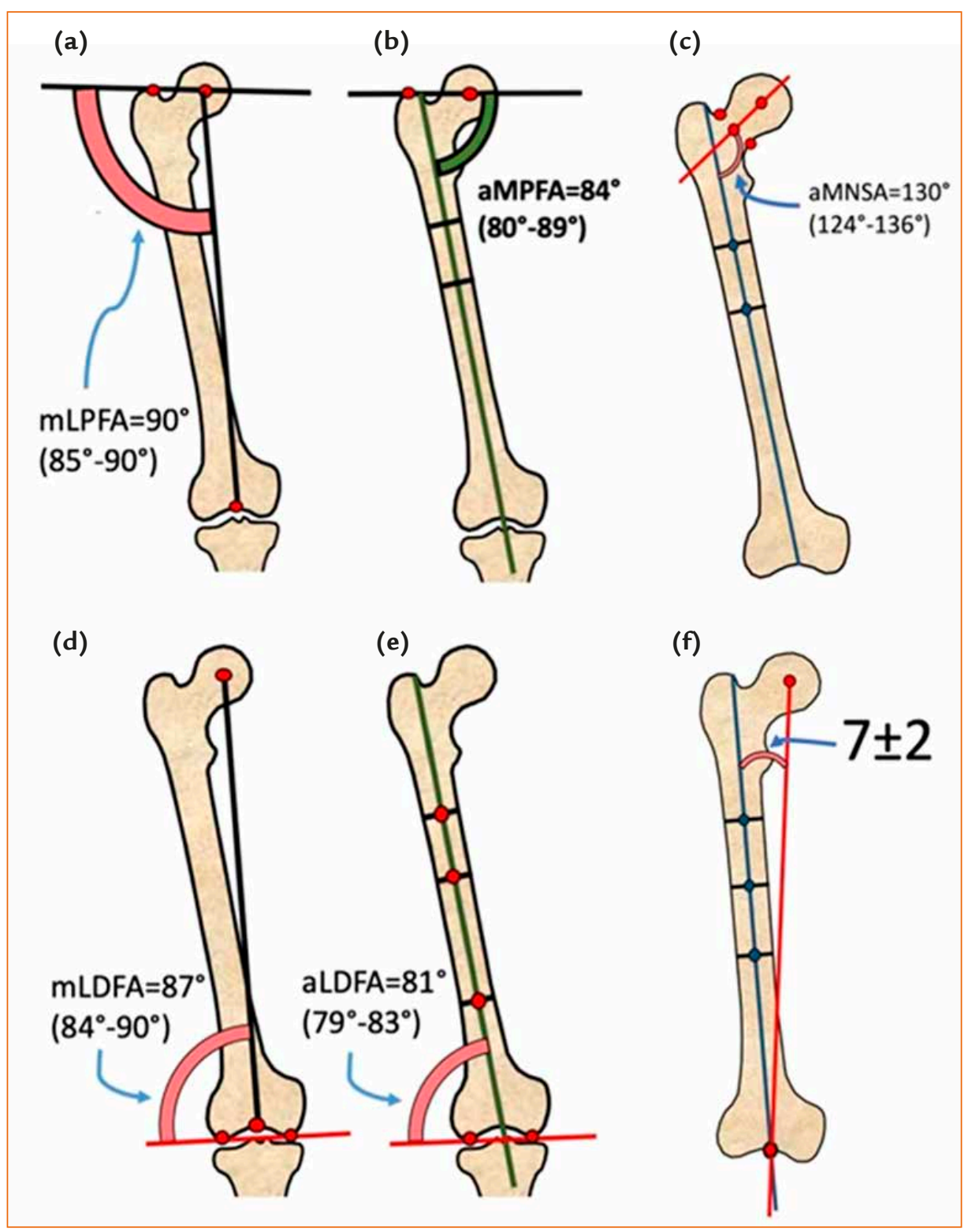

Şekil 3. a-f. Femur proksimal eklem oryantasyon açları, anatomik ve mekanik ekseninin görselleştirilmesi. Mekanik eksene göre lateral proksimal femoral açı (a). Anatomik eksene göre medial proksimal femoral açı (b). Anatomik eksene göre medial baş boyun açısı (c). Femur mekanik ekseni ve mekanik eksene göre lateral distal femoral açı (d). Femur anatomik ekseni ve anatomik eksene göre lateral distal femoral açı (e). Femur mekanik ve anatomik eksenler arasındaki ilişki (f). (Çakmak M, Şen C, editörler. Deformite Cerrahisinde ilizarov Uygulamaları. İstanbul: Nobel Tıp Yayınevi; 2014'ten izinle alıntılanmıştır.)

çizgileri ve açıları çizilir. Femur analizinde proksimal femurun anatomik ekseni çizilir ve femur başından geçecek şekilde mediale kaydırılır. Mekanik eksene dönüştürmek için femur başı orta noktasından kaydırılan eksen ile $7^{\circ}$ lik açı yapacak şekilde distale doğru uzatılır. Böylelikle proksimal kısmın mekanik ekseni çizilmiş olur. Proksimal ve distal mekanik eksenler bileşke (çözüm) CORA'sında (Centre of Rotation of Angulation) birleşir ve bu nokta deformitenin gözle görülür tepe noktalarına yakın bir noktadadır (uniapikal deformite) (Şekil 6b). Bu nokta üzerinden, deformite açısı kadar düzeltme yapılarak diyafizer deformiteler düzeltilir. ${ }^{[2]}$

Eğer kalça ekleminde deformite varsa, proksimal femoral eklem oryantasyon çizgileri çizilerek proksimaldeki CORA bulunur. Trokanter minör seviyesinden yapılacak bir osteotomi ile deformite düzeltilir. 


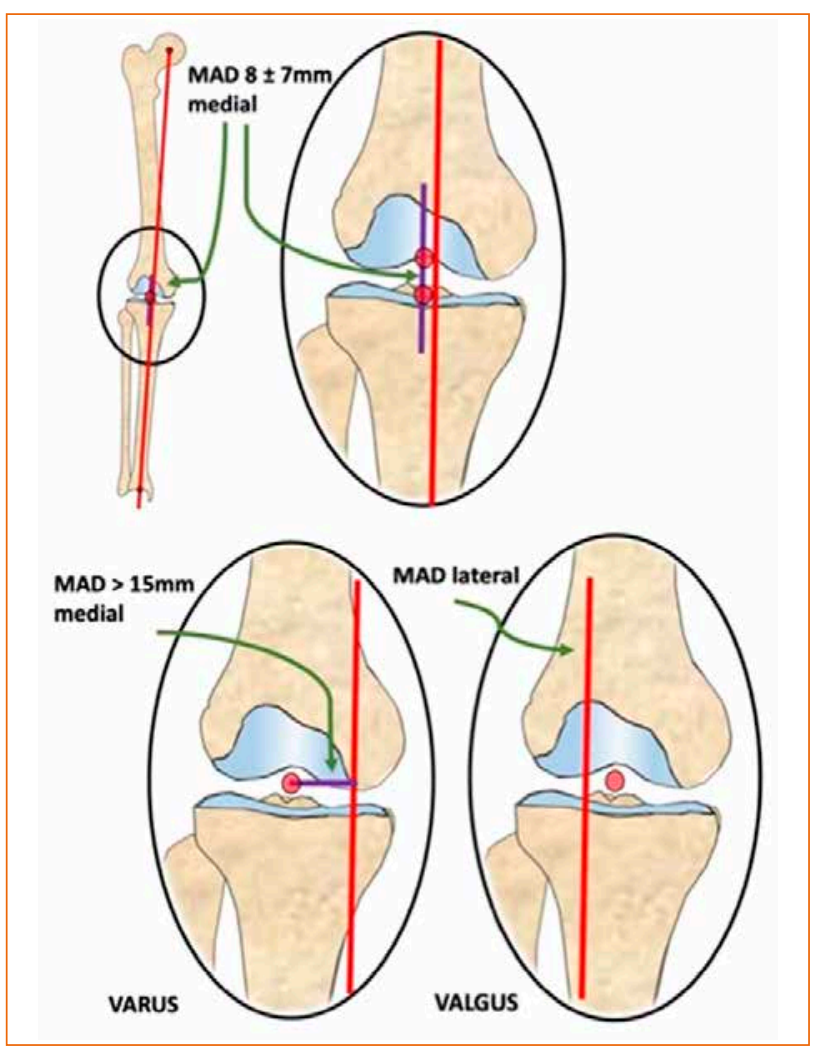

Şekil 4. Alt ekstremite mekanik ekseni normalde diz eklemi orta noktası medialinden geçer. Lateralden geçtiği her durum ve 15 mm'den fazla medialize olduğu durumlar mekanik eksen sapması olarak tanımlanır. Bu durum kötü dizilim testinin ilk basamağında uygulanır. (Çakmak M, Şen C, editörler. Deformite Cerrahisinde Illizarov Uygulamaları. İstanbul: Nobel Tıp Yayınevi; 2014'ten izinle alıntılanmıştır.)

Bu düzeltme ikinci osteotomi kuralı ile yapılacağı için translasyon kaçınılmaz olacaktır. Osteotomi şeklinin transverse yapıldığı durumlarda, düzeltmeye eklenen translasyon ile birlikte temas alanı daha da azalacaktır. Distal femur deformitelerinde mekanik eksenler kesişiminde tespit edilen CORA noktası, eklem üzerinde ya da distal femoral epifiz sınırları içerisinde olacaktır. Bu durumlarda osteotomi bir miktar daha proksimalden ikinci kural ile yapılır. Translasyon kaçınılmazdır (Şekil 7).

Deformite analizi yapıldıktan sonra, hasta henüz ameliyat edilmeden önce, boy grafileri üzerinden şabIon çalışması yapılması önemlidir. Bu çalışmalar kopya kağıtları üzerinden veya basılı röntgenler vasıtası ile yapılabildiği gibi, günümüzde bu iş için geliştirilmiş uygulamalar kullanılarak da yapılabilir. Ameliyatların bu şekilde önceden taklit edilmesi, ostetotomi yerlerinin belirlenmesinde ve ameliyat sonuçlarının ön görülmesinde yardımcı olur (Şekil 8).

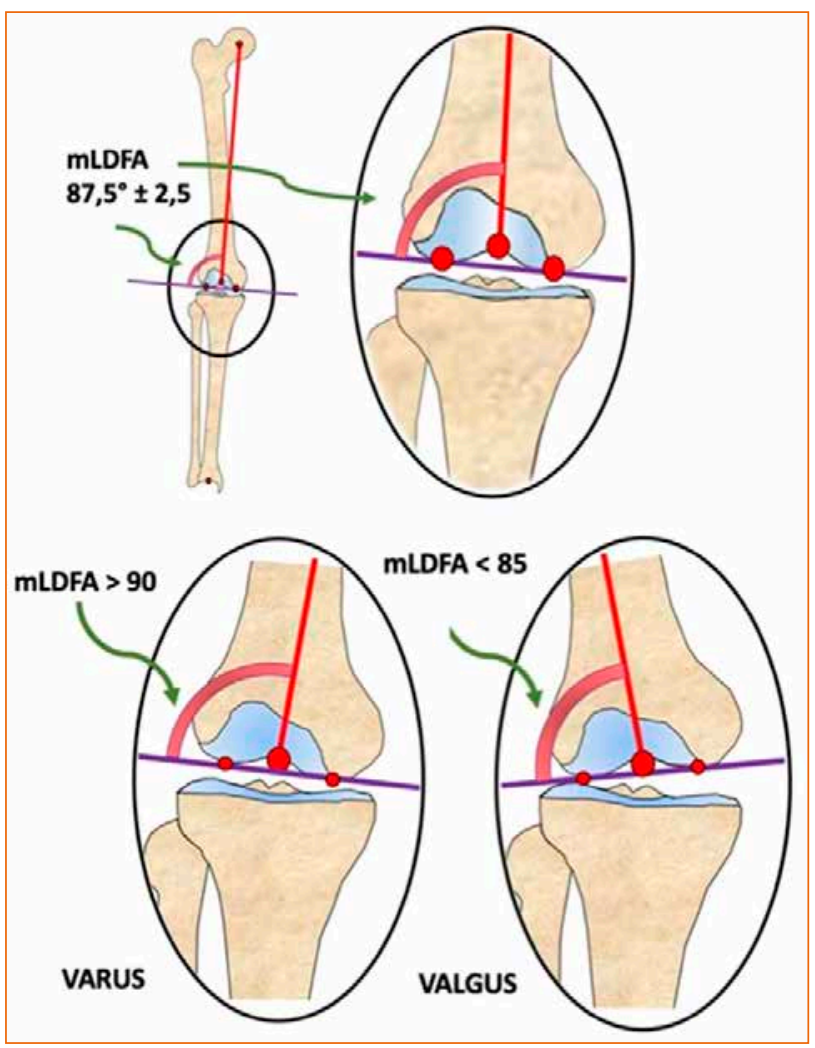

Şekil 5. Distal femur eklem oryantasyon açısına göre maloryantasyonun tespit edilmesi. (Çakmak M, Şen C, editörler. Deformite Cerrahisinde ilizarov Uygulamaları. Istanbul: Nobel Tıp Yayınevi; 2014'ten izinle alıntılanmıştır.)

Deformite düzeltme ameliyatı planlanan her hastanın ameliyat öncesinde eğer varsa ekstremite eşitsizlikleri belirlenmelidir. Bu hastanın boy grafilerinin çekilmesi esnasında kısa tarafın altına konulan bir telafi ile de yapılabilir. Bu sayede hastaların dökümantasyonu daha doğru olacak ve pelvisin tam yatay durduğu uzatma hedefi tespit edilebilecektir.

\section{TEDAVIDE KULLANILAN TEKNIKLER}

\section{Klasik ilizarov Tekniği}

Deformite analizi yapıldıktan sonra, ameliyattan en az bir gün önce çerçeve hazırlanmalı, hasta üzerinde röntgen ile denenmeli ve sterilize edilmelidir. Çerçevede, distal femur deformiteleri için CORA'nın distaline ve proksimaline yerleştirilen birer halka, menteşe ve motor ünite ile birleştirilir. Proksimalde ise L-konnektörler ve pelvik yaylar kullanılarak çerçeve tamamlanır. Subtrokanterik bölgeden yerleştirilen Schanz vidaları ile proksimal tespit, delta 

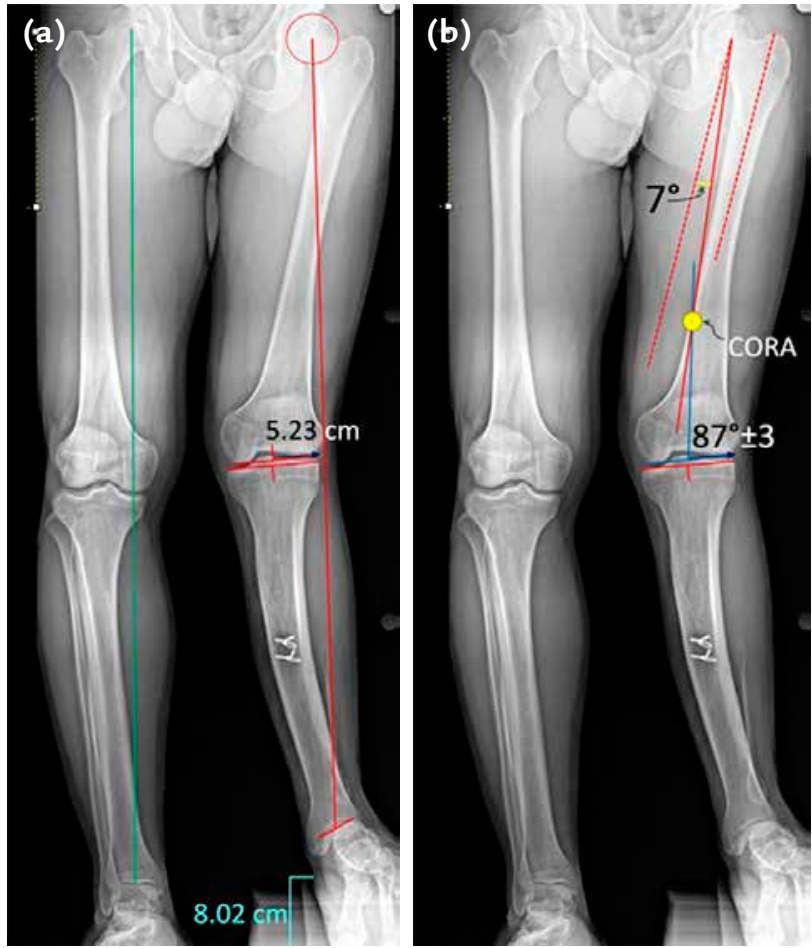

Şekil 6. a, b. Mekanik eksende laterale sapması olan fibular hemimeli hastası. Hastanın ortoröntgenografisinin telafi kullanılarak ve pelvisin yere paralel hale getirilerek çekildiğine dikkat ediniz (a). Proksimal femur anatomik ekseni medialize edilip, $7^{\circ}$ açı verilerek mekanik eksen çizilir. Distalde uygun açıdan proksimale doğru uzatılan mekanik eksen ile kesişim noktası CORA'yı gösterir (b).

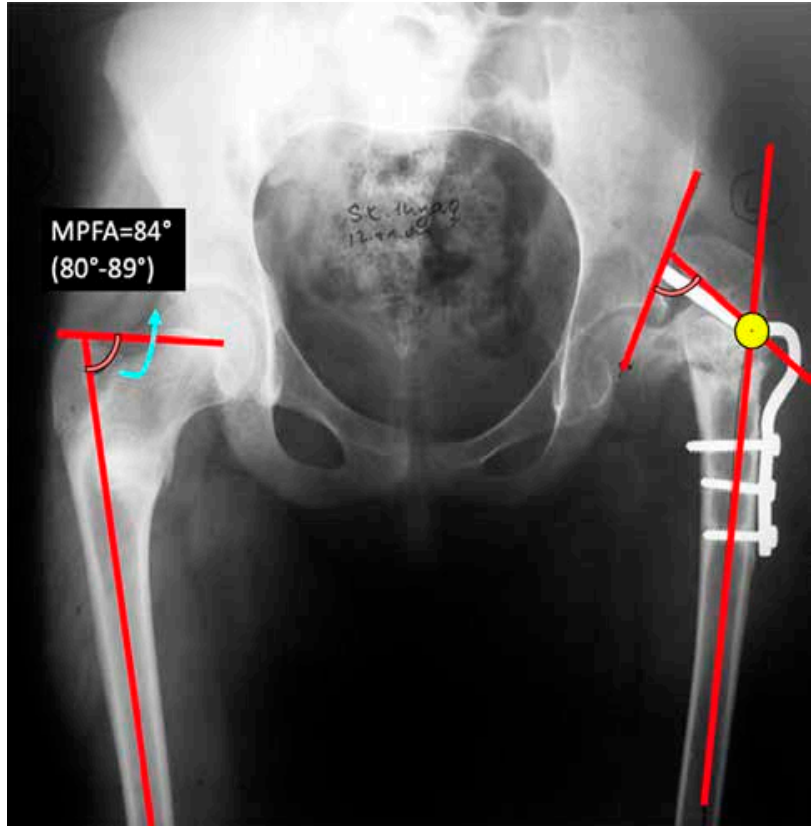

Şekil 7. Proksimal femur deformitesinde eklem oryantasyon çizgisinin çizilmesi ve CORA'nın bulunması. Hedeflenen düzeltme miktarı karşı kalçanın açılarının simüle edilmesi ile planlanabilmektedir. (İstanbul Tıp Fakültesi, ilizarov Arşivi'nden alınmıştır.)

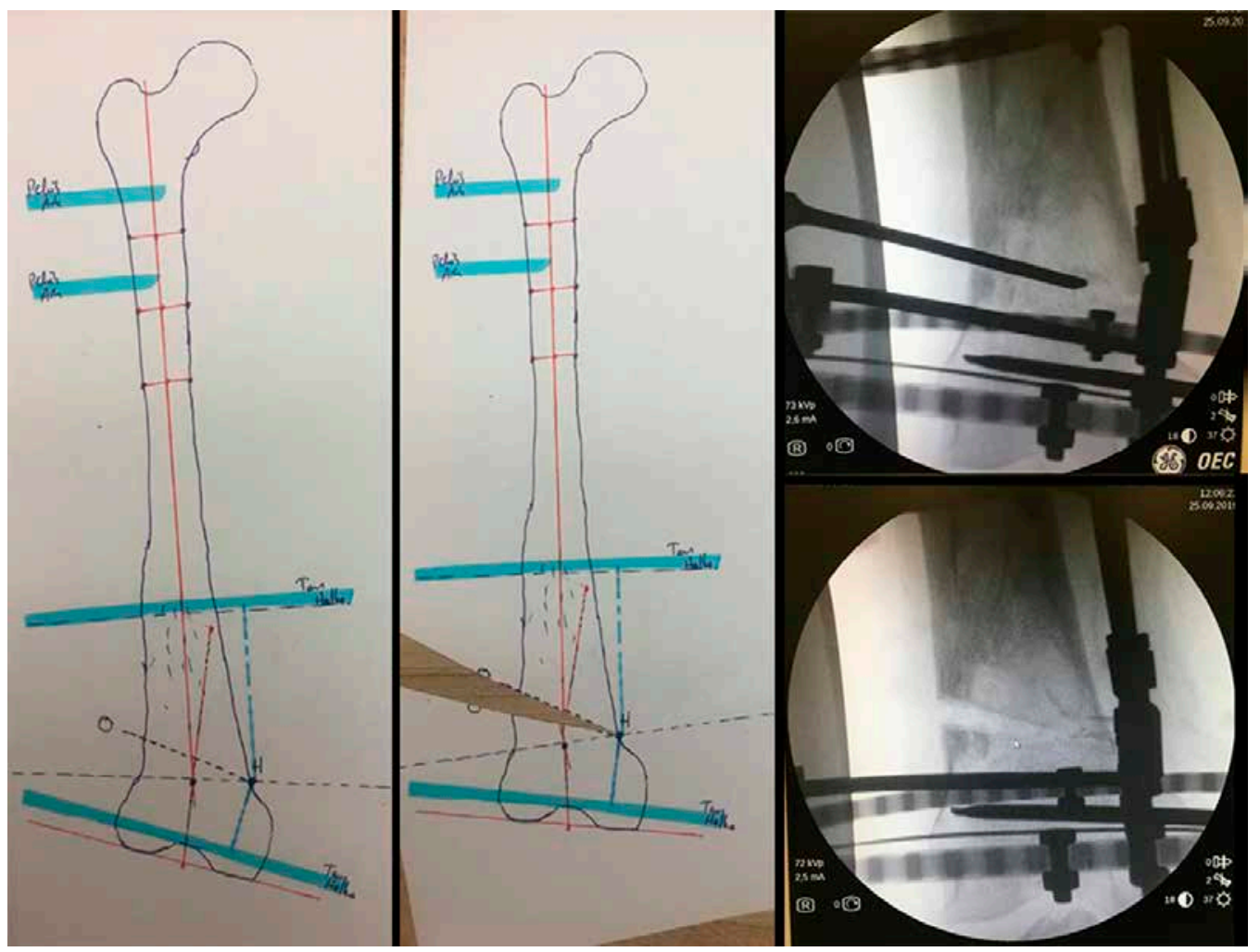

Şekil 8. Distal femurda post-travmatik uniapikal valgus deformitesi olan bir hastanın preoperatif şablon çalışması. Şablon çalışmasında planlanan osteotomi ve menteşe planlamasının, ameliyat içi floroskopilerde uygulanışına dikkat ediniz. 


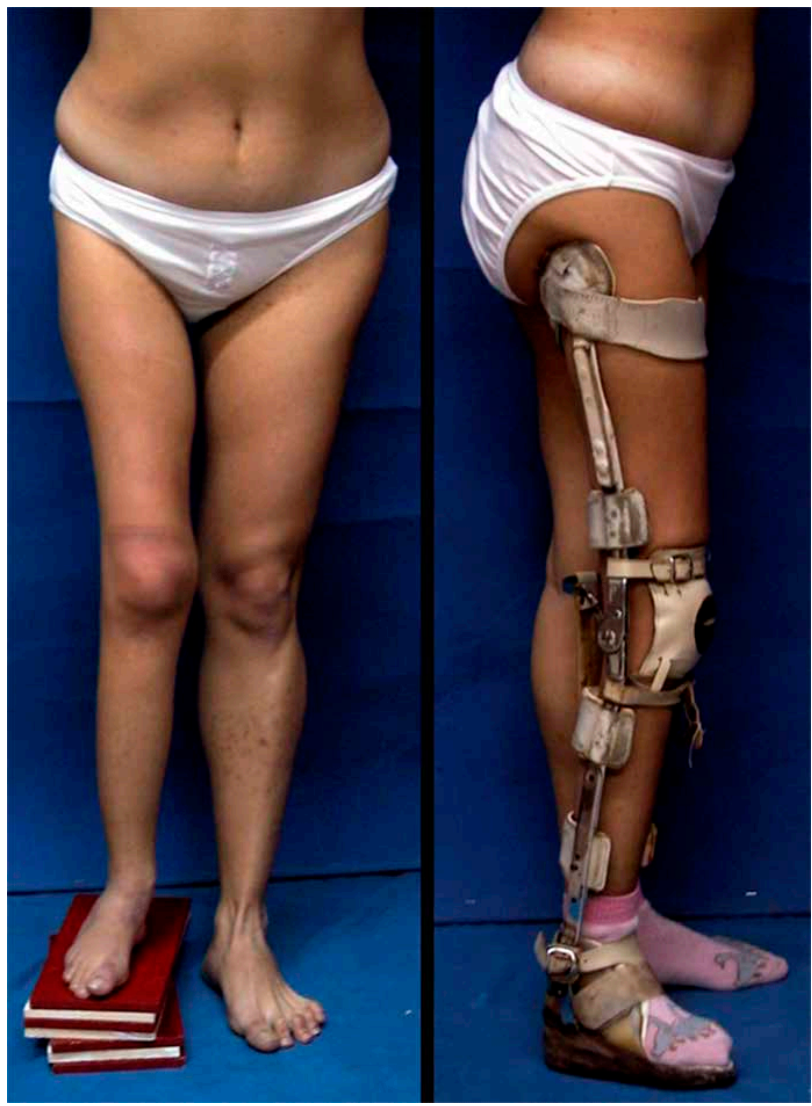

Şekil 9. Polyomiyelit sebebi ile sağ alt ekstremitesinde kısalık olan hastanın tedavi öncesi klinik görünümü (solda) ve yürümek için kullandığı cihazı (sağda).

konfigürasyonunda yerleştirilen distal tespit ve yine Schanz vidaları ile yerleştirilen orta tespit sonrasında planlanan seviyeden osteotomi yapılır. Eğer CORA ekleme çok yakın ise transvers osteotomi için translasyon sonrası yeterli kemik teması kalacak kadar proksimale çıkılmalıdır. Deformite akut ya da tedrici olarak düzeltilebilir. Tedrici düzeltmelerde latent periyod beklenmeli sonrasında çevirme yapılmalıdır. Motor ünite menteşeye uzak yerleştirileceği için, motor ünitede yapılan her bir milimetrelik çevirmenin, osteotomi sahasında çok daha az bir oranda etki edeceği unutulmamalıdır (benzer üçgenler kuralı). Bu sebeple çevirmeler günde 3-4 mm olacak şekilde planlanır. Aynı zamanda kısalık tedavisi yapılacaksa, deformite düzeltildikten sonra menteşeler uzatma rodları ile değiştirilerek, uzatma yapılabilir (Şekil 9-11). ${ }^{[3]}$

\section{Unilateral Fiksatör ile Deformite Düzeltme Tekniği}

Unilateral fiksatörler, sirküler fiksatörlere göre daha konforlu enstrümanlardır. Ancak stabilitesi sirküler fiksatörlerden düşüktür. Uygulamada

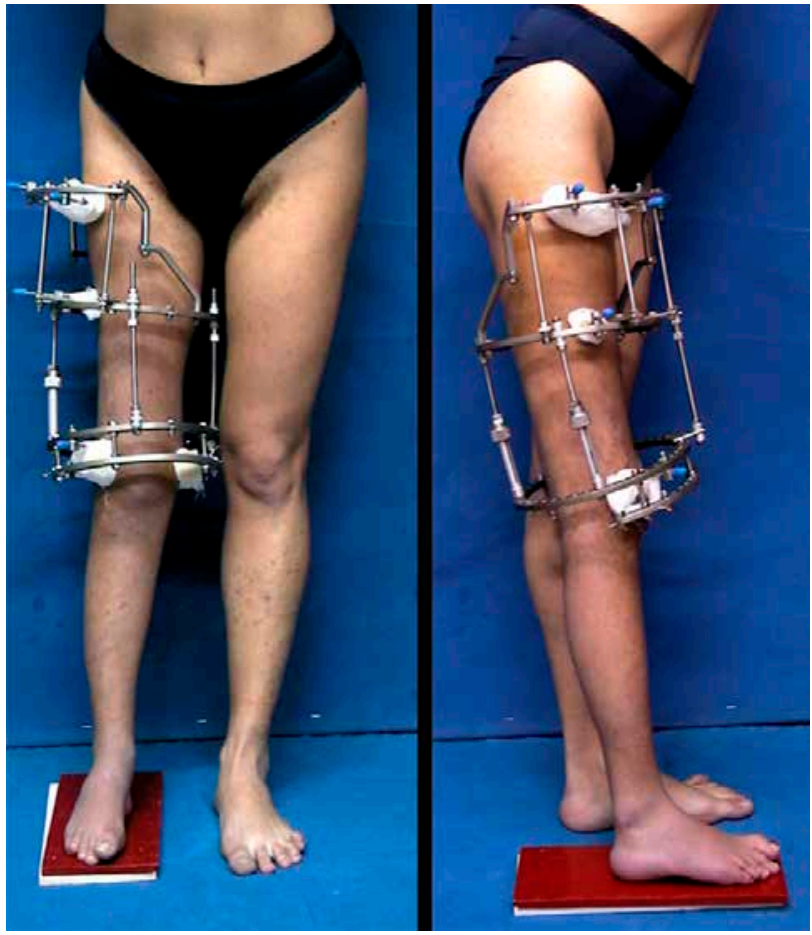

Şekil 10. Hastanın fiksatör yerleştirildikten sonraki ön ve yan klinik fotoğrafi. Sirküler fiksatörün femurda sabitlenme şekline dikkat ediniz. L-konnektörler ile femur proksimaline doğru enstrümanların sadece lateralde kullanımı hasta konforuna olanak sağlamaktadır. Poliomiyelitte görülen sarsak diz yürüyüş̧ü (flail knee) sebebi ile hastaya sagittal plan ekstansiyon osteotomisi uygulanmıştır. Fiksatörün posteriorundaki uzatma rodlarına dikkat ediniz.

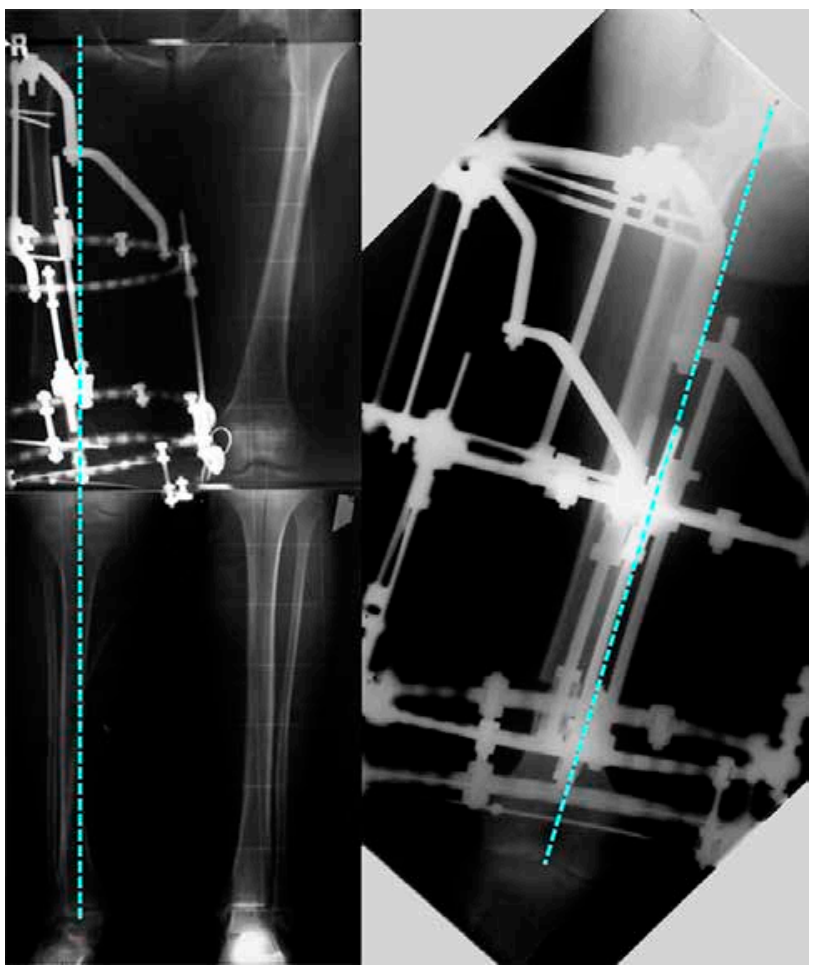

Şekil 11. Hastanın uzatma sonrası ortoröntgenogramı. 


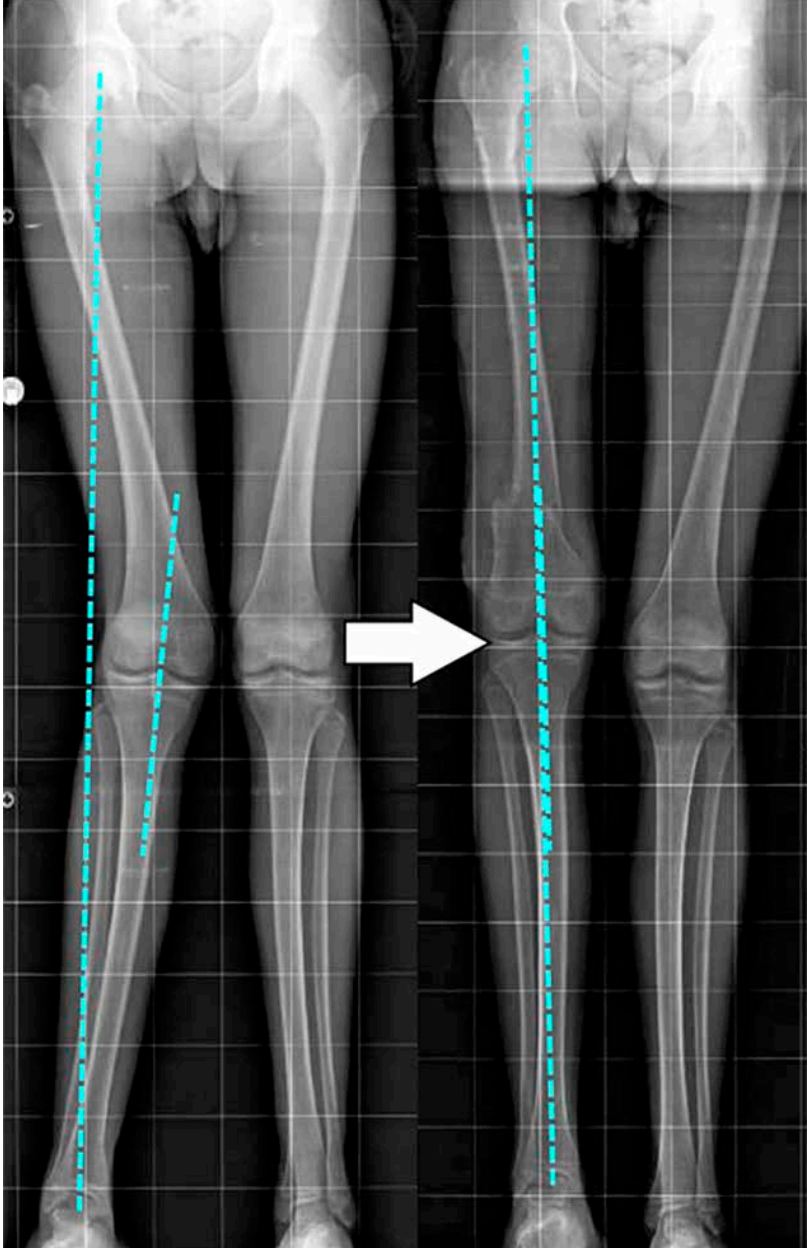

Şekil 12. Distal femoral valgus deformitesi olan hastanın ameliyat öncesi ve sonrası radyografik görüntüsü. Hastada mekanik eksenin santralizasyonuna dikkat ediniz. kolaylık ve anatomik uygunluk sebebi ile özellikle femur deformitelerinde ve uzatmalarında tercih edilirler. Unilateral fiksatörlerin uygulanması esnasında eğer varsa rotasyonel deformiteler akut olarak düzeltilmelidir. Eklem maloryantasyonları ise açılandırılabilen tutucular ile hem akut hem de tedrici olarak düzeltilebilir. Ancak tespitin tek planda yapılmasından dolayı, aksiyal deviasyon, sagital plan açılanmaları ve implant yetmezlikleri görülebilir. Özellikle kemik kalitesinin düşük olduğu durumlarda, unilateral fiksatör tercih edilecekse hidroksiapatit kaplı (HA-Coated) Schanz vidaları, stabilitenin artırılmasına yardımcı olur. Femurda unilateral fiksatör ile yapılacak tüm ameliyatların, ilizarov tipi sirküler fiksatörler ile de yapılabileceği unutulmamalıdır (Şekil 12, 13). ${ }^{[4]}$

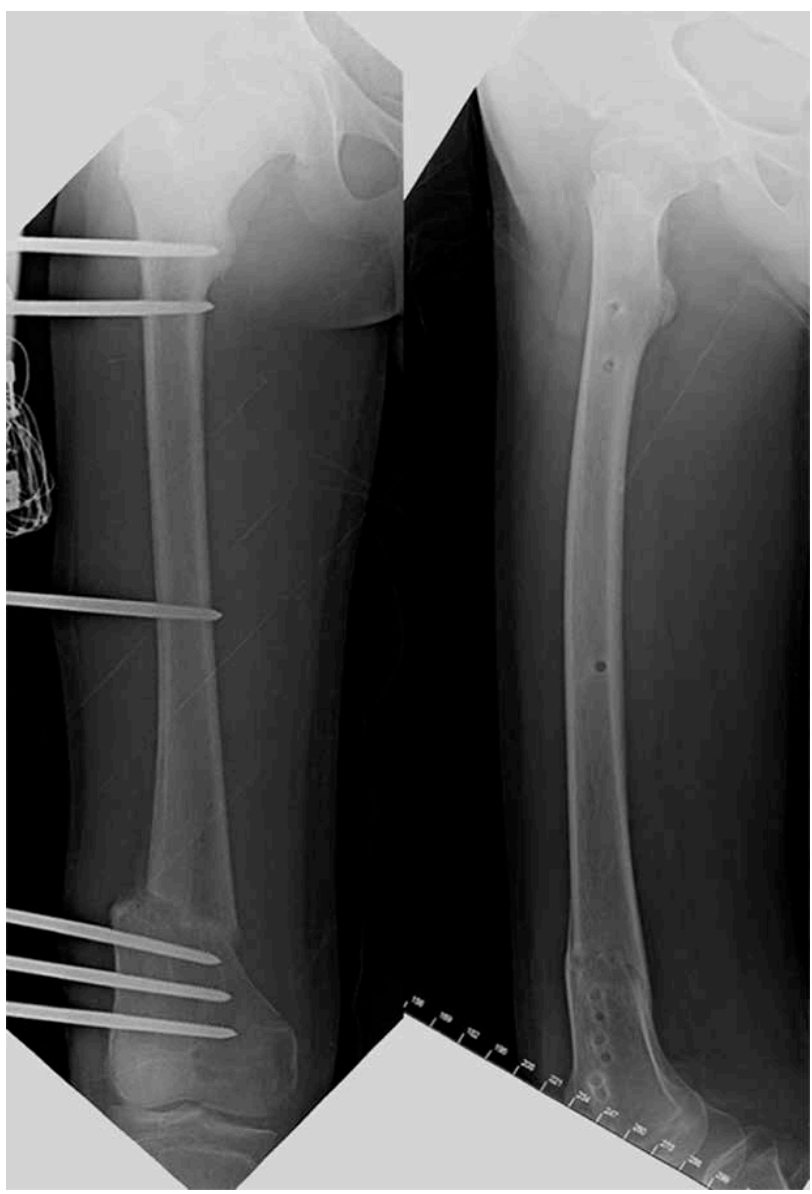

Şekil 13. Aynı hastanın unilateral fiksatör çıkartılmadan önce (solda) ve sonra (sağda) çekilmiş femur röntgenleri. Hastanın sagittal planda aksiyal deviyasyon olmadan tedavi edildiğine dikkat ediniz. Unilateral fiksatörlerde aksiyal deviasyon kolaylıkla görülebilecek bir komplikasyondur.

\section{Fiksatör Yardımlı Çivileme Tekniği (FAN)}

$\mathrm{Bu}$ teknik uniapikal deformitelerin yanısıra, multiapikal deformitelerin tedavisinde ya da metabolik hastalıklara bağlı gelişen yay (bowing) deformitelerinde kullanılır. Uniapikal deformiteler ise fiksatör kalış süresinin kısaltılması planlandığında, kemik kalitesinin kötü olduğu durumlarda ya da uzatma tedavisinin de aynı anda uygulanması gereken olgularda FAN (fixator assisted nailing) ile tedavi edilebilir. Tekniğin uygulanabilmesi için hem eksternal fiksatör hem de intramedüller çivi uygulama prensiplerine hakim olunmalıdır. Intramedüller çivi kullanımının kontrendike olduğu durumlarda FAN uygulamalarından kaçınılmalıdır. FAN ile çivi üzerinden uzatma ardışık olarak uygulanabilir (FAN-LON [lengthening 


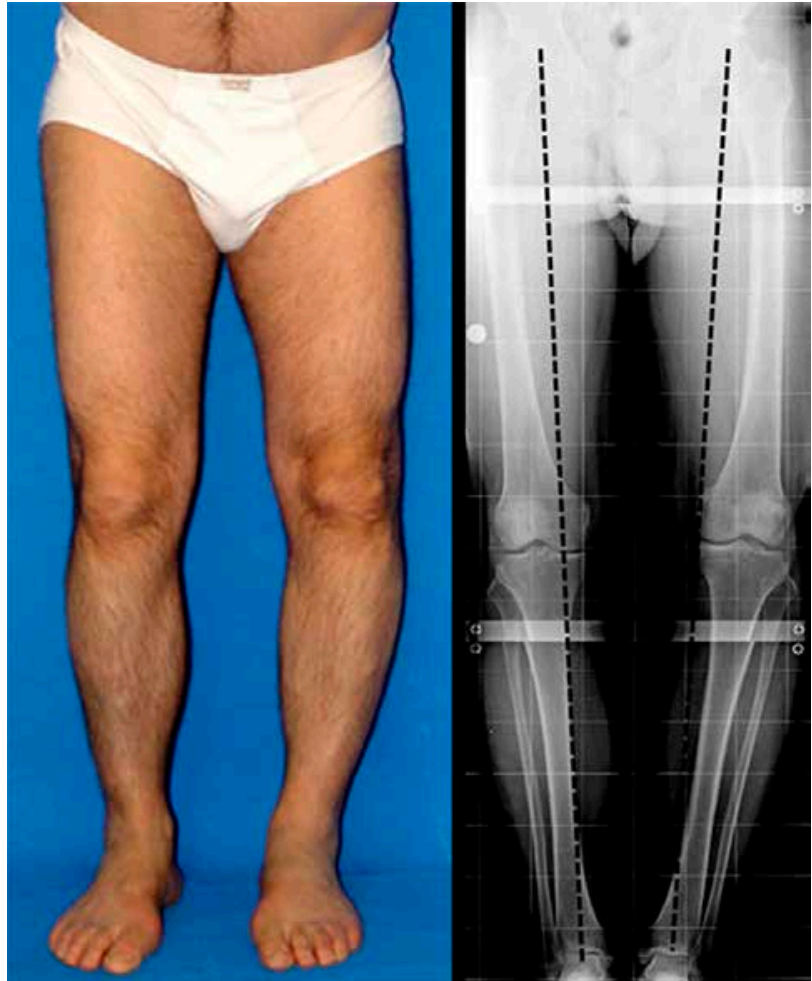

Şekil 14. Sol dizde medial aks deviyasyonu olan hastanın ameliyat öncesi klinik (solda) ve radyolojik (sağda) görünümü.

over nails]). Bu kombinasyon, konsolidasyon fazının fiksatörsüz geçirilmesine olanak sağlar ancak klasik ilizarov gibi sonradan düzeltme ve modifiksayon seçeneklerini ortadan kaldırır. Sonuç olarak, pahalı ve tecrübe gerektiren bir yöntemdir. FAN-LON tekniği ayrı bir bölüm olarak anlatılmıştır. ${ }^{[5]}$

\section{Sadece İntramedüller Çivi ile Deformite Düzeltme Tekniği}

Femur uniapikal deformitelerin tedavisi için fiksatör kullanımı şart değildir. Uygun pozisyonlanan polar vidalarının da yardımı ile intramedüller çivi ile femur deformiteleri düzeltilebilir. Antegrad ya da retrograd çivi tercih edilebilir. Intramedüller çivi planlamasında çivi giriş yeri, osteotomi sahasının seçimi, polar vida konfigürasyonunun belirlenmesi ve çivinin çıkış doğrultusunun doğru belirlenmesi önemli noktalardır. Baştan doğru olmayan bir şekilde yerleştirilen intramedüller çivi ek deformitelere yol açabilir. İntramedüller çivi kullanımında tüm deformiteler akut olarak düzeltilir. Emboli ve enfeksiyon riski unutulmamalıdır. Motorize çivi kullanımında, deformite düzetme sonrası uzatma yapılabilir (Şekil 14-16). ${ }^{[6]}$

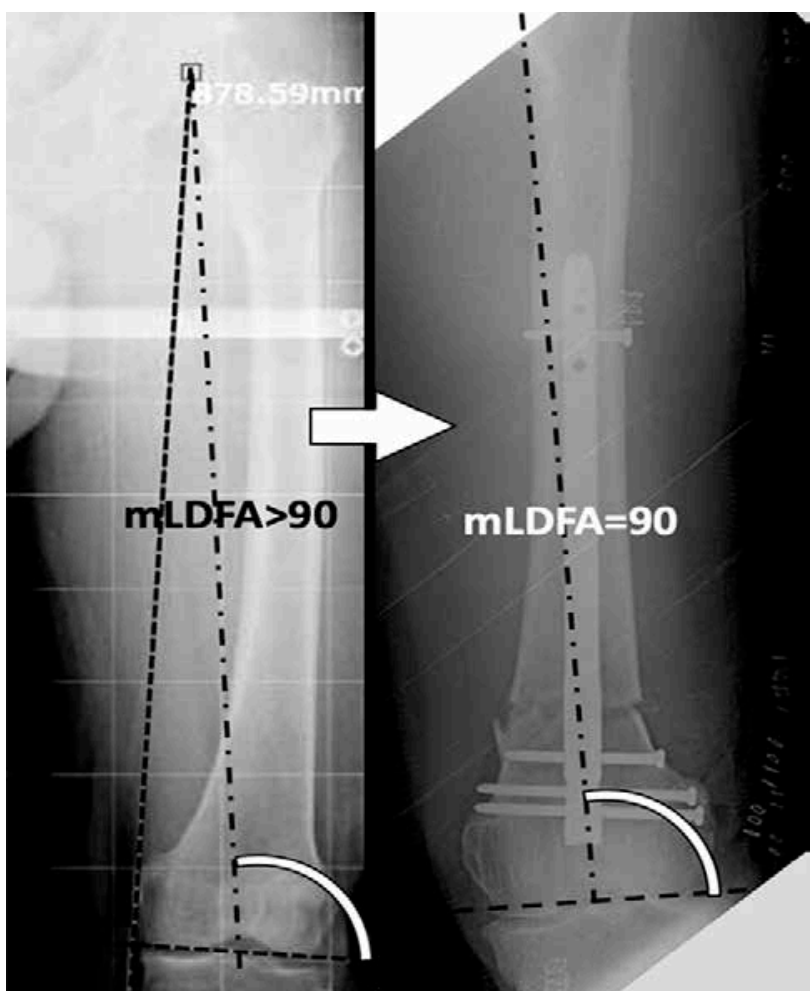

Şekil 15. Hastanın femur kaynaklı varus deformitesini düzeltmek amacı ile intramedüller retrograd çivileme uygulanmış. Ameliyat öncesi (solda) ve ameliyat sonrası (sağda) mLDFA değişimine dikkat ediniz.

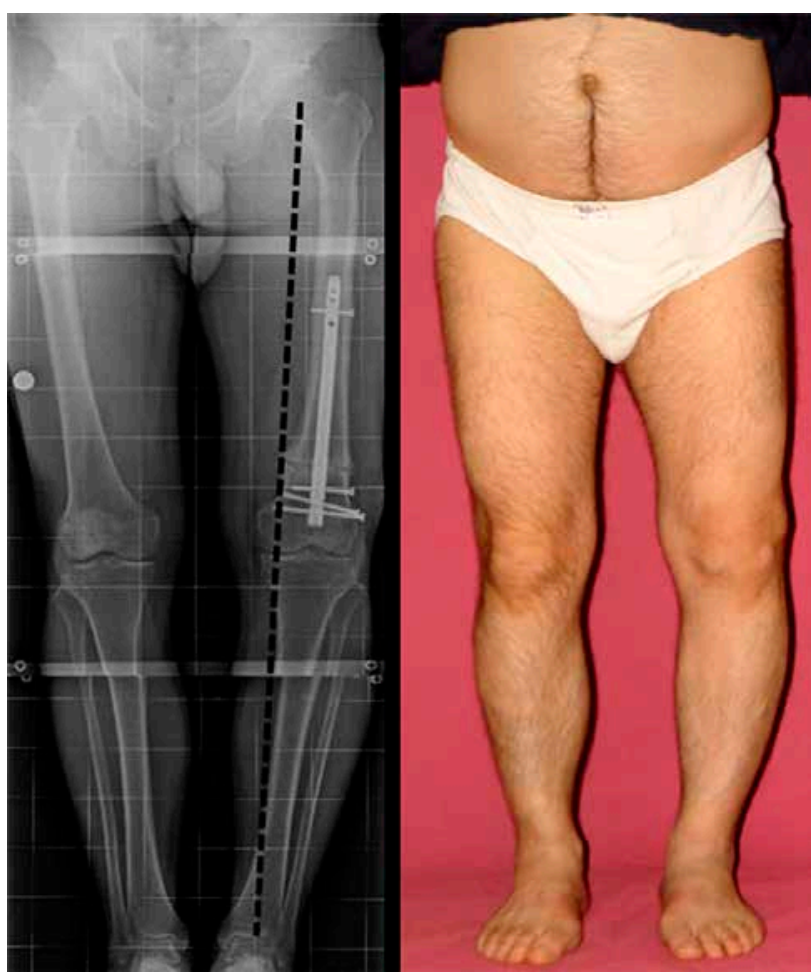

Şekil 16. Femur kaynaklı varus deformitesi düzeltilen hastanın ameliyattan sonra mekanik aksındaki lateralizasyonu (sağda) ve klinik fotoğrafi (solda) 


\section{Plak Vida ile Deformite Düzetme}

Diyafizer femur deformitelerinin plak vida ile akut düzeltilmesi, günümüzde neredeyse terk edilmiş bir tekniktir. Sıklıkla AO prensipleri kullanılarak, Avrupa kökenli cerrahların tercih ettikleri bu yöntem günümüzde modifiye osteotomiler ile sadece proksimal ve distal femur deformitelerinde kullanılmaktadır. Hem proksimal hem de distal femur deformitelerinde plak vida ile varizasyon, valgizasyon, translasyon, derotasyon ve bunların kombinasyonları yapılabilmektedir. Aynı preoperatif hazırlık aşamaları ve şablonlama teknikleri kullanılır. Ameliyatların önceden simüle edilmesi ile daha başarılı sonuçlar elde edilir. ${ }^{[7]}$

\section{SONUÇ}

Femurun uniapikal deformiteleri; iyi bir analiz, ameliyat öncesi planlama ve doğru tekniklerin seçimi ile başarılı bir şekilde tedavi edilebilir. Aynı deformite için birden fazla tedavi seçeneğinin olması, bu ameliyatlarda sıklıkla ameliyat sonrası sorgulamalara sebep olur. Ancak önemli olan deformite analizinin temel prensiplerine göre; önce deformitenin (dizilim bozukluğunun) olduğunun tespit edilmesi, daha sonra deformitenin femurun hangi bölgesinden kaynaklandığının bulunması, en sonunda ise CORA'nın tespit edilerek osteotomi yerine karar verilmesidir. Bütün bunlar doğru bir şekilde yapıldıktan sonra, osteosentezin hangi yöntemle yapılacağı, tamamen cerrahın kişisel tercihine bağlıdır. Cerrah hangi yöntemde kendini daha tecrübeli görüyorsa, o tekniği seçmelidir. Çünkü önemli olan, deformitenin en doğru şekilde düzeltilmesidir.

\section{KAYNAKLAR}

1. Paley D. Principles of Deformity Correction. Berlin: Springer; 2002.

2. Paley D, Tetsworth K. Mechanical axis deviation of the lower limbs. Preoperative planning of uniapical angular deformities of the tibia or femur. Clin Orthop Relat Res 1992;(280):4864. Crossref

3. Yeu K, Huang SC, Liu TK. Treatment of malunion of the lower extremities by the llizarov technique. J Formos Med Assoc 1994;93:403-10.

4. Civan M. Parts of Ilizarov-type external fixators. In: Çakmak M, Şen C, Eralp L, Balci HI, Civan M, editors. Basic Techniques for Extremity Reconstruction. Switzerland: Springer; 2018. pp.27-35.

5. Paley D, Herzenberg JE, Paremain G, Bhave A. Femoral lengthening over an intramedullary nail. A matched-case comparison with llizarov femoral lengthening. J Bone Joint Surg Am 1997;79:1464-80. Crossref

6. Saravanaraja M, Rozbruch SR, Fragomen AT. The use of blocking screws with internal lengthening nail and reverse rule of thumb for blocking screws in limb lengthening and deformity correction surgery. Strategies Trauma Limb Reconstr 2016;3:199-205. Crossref

7. Kovar FM, Jauregui JJ, Herzenberg JE. Accuracy of Distal Femoral Valgus Deformity Correction: Fixator-Assisted Nailing vs Fixator-Assisted Locked Plating. Am J Orthop (Belle Mead, NJ) 2018;47. Crossref 